Issue 1/2018

\title{
EFFECT OF FOREIGN EXCHANGE RATE FLUCTUATIONS ON NIGERIAN ECONOMY
}

\author{
Lawrence Olisaemeka UFOEZE ${ }^{1}$, Camilus N. OKUMA ${ }^{2}$, Clem NWAKOBY ${ }^{3}$, \\ Udoka Bernard ALAJEKWU ${ }^{3}$ \\ ${ }^{1}$ Department of Banking and Finance, Chukwuemeka Odumegwu Ojukwu \\ University, Anambra State, Nigeria \\ ${ }^{2}$ Department of Banking and Finance, Madonna University, Okija Campus, \\ Anambra State, Nigeria \\ ${ }^{3}$ Department of Banking and Finance, Nnamdi Azikewe University, Anambra \\ State, Nigeria, Tel.: +2347030997856, Email: blueben2010@yahoo.com
}

\begin{abstract}
This study investigated the effect of exchange rate fluctuations on Nigerian economy. The fixed and floating exchange eras were compared to know the exchange rate system in which the economy has fairly better. The time period covered was 1970 to 2012. The study employed the ordinary least square (OLS) multiple regression technique for the analysis. The coefficient of determination $\left(R^{2}\right)$, F-test, t-test, beta and Durbin-Watson were used in the interpretation of the results. The resulted revealed that about $85 \%$ of the changes in macroeconomic indicators are explained in the fixed exchange era. In the floating exchange era, 99\% was explained while the whole periods has $73 \%$ explanatory power, hence the floating exchange era (1986 to date) is more effective in explaining economic trends in Nigeria. Also, exchange rate has significant positive effect on GDP during the fixed exchange rate era and negative effect during the eras floating and all-time; inflation has insignificant negative effect on GDP during the fixed exchange era; significant effect in floating era and significant negative effect in the all-time period; money supply has insignificant negative effect on GDP during the fixed exchange era; and significant positive effect during the floating and all-time period; and oil revenue has significant positive effect on the GDP in all the exchange rate regimes (floating, fixed and all-time) in Nigeria. The study thus concludes that exchange rate movement is a good indicator for monitoring Nigerian economic growth. So far, exchange rate has always been a key economic indicator for Nigeria. The floating exchange period has outperformed the fixed exchange rate in terms of contribution inflation, money supply and oil revenue to economic growth. This indicates that the floating exchange rate has been a better economic regime for sustainable economic growth in Nigeria.
\end{abstract}




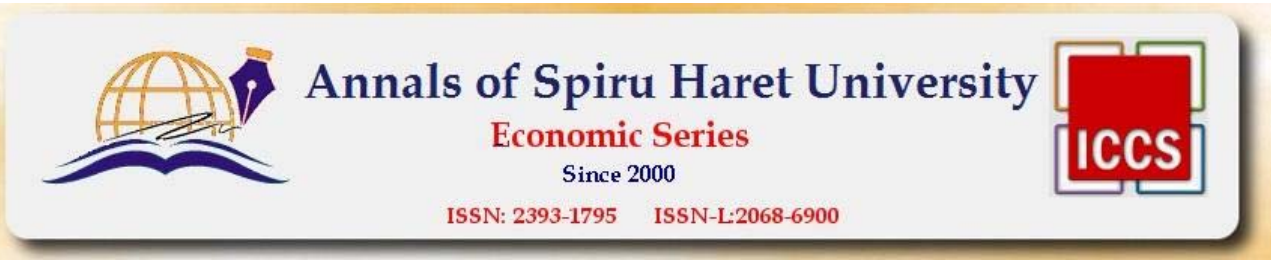

Issue $1 / 2018$

From the findings, it is evident that oil revenue has positive effect in Nigeria and has remained the mainstay of the economy. It is thus recommended, among other things, that the positive exchange rate stock be monitored regularly, so as not to allow those that find exchange rate as an avenue of investment, such as banks and the public, carry out their business, a thing which is more devastating to the economy.

Keywords: exchange rate fluctuation; inflation; money supply; oil revenue; gross domestic product.

JEL Classification: $F_{31}, F_{43}$

\section{Introduction}

\subsection{Background to the study}

The principle of comparative advantage encouraged nations to specialise in the production of the products for which they can easily produce at cheaper rate and in abundance so as to exchange it with other products from other countries. This economic principle had encouraged economic liberalisation. Economic liberalisation allowed countries to seek exchange of resources (goods and services) with one another. Hence, the concept of exchange rate as a factor crept into the analysis of economic growth.

It did not feature in the first generation neoclassical growth model Solow (1957) and Rostow (1960) (as contained in Todaro \& Smith, 2004) which focused on savings and investment. The fact that they were closed economy models dictated that there is no role for exchange rate or exchange rate volatility. The exchange rate is perhaps one of the most widely discussed topics in Nigeria today. This is not surprising given its macroeconomic importance especially in a highly import dependent economy as the Nigerian one [Olisadebe, 1991]. Thus, the use of exchange rate as an incentive to shift resources into export sector became a policy of interest as a way of boosting national income [Oyovwi, 2012].

In Nigeria, the exchange rate policy has undergone substantial transformation from the immediate post-independence period when the country maintained a fixed parity with the British pound, through the oil boom of the 1970s, to the floating of the currency in 1986, following the near collapse of the economy between 1982 and 1985 period [Akpan \& Atan, 2012]. In each of these epochs, the economic and political considerations underpinning the exchange rate policy had important 


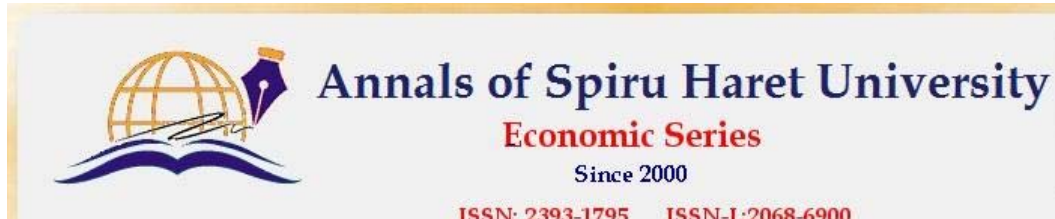

ISSN: 2393-1795 ISSN-I-2068-6900

Issue 1/2018

repercussions for the structural evolution of the economy, inflation, the balance of payments and real income.

Exchange rate is an important macroeconomic policy instrument. Changes in exchange rates have powerful effects on tradable and non-tradable of countries concerned through effects of relative prices of goods and services [Bobai, Ubangida \& Umar, 2013]. More particularly, there has been an ongoing debate on the appropriate exchange rate policy in developing countries [Kandil, 2004]. The debate focuses on the degree of fluctuations in the exchange rate in the face of internal and external shocks. Exchange rate fluctuations are likely, in turn, to determine economic performance. In judging the desirability of exchange rate fluctuations, it becomes, therefore, necessary to evaluate their effects on the performances of macroeconomic variables in Nigeria.

\subsection{Statement of the problem}

The exchange rate of the naira was relatively stable between 1973 and 1979, during the oil boom (regulatory era). This was also the situation prior to 1970, when agricultural products accounted for more than $70 \%$ of the nation's gross domestic products (GDP) [Ewa, 2011]. However, as a result of the development in the petroleum oil sector, in 1970's the share of agriculture in total exports declined significantly, while that of oil increased. However, from 1981, the world oil market started to deteriorate and its economic crises emerged in Nigeria because of the country's dependence on oil sales for her export earnings. Since the Nigerian economy has remained import-dependent and oil-supported, the fluctuation of oil prices would have effect on Nigeria's oil revenue (the major source of income). This study thus is faced with the determining whether the exchange rate has any bearing on Nigerians economic growth and other macroeconomic policy variables.

More so, extant literatures on exchange rate fluctuation are mixed and conflicting. Similar studies are those of Aliyu (2009), Akpan (2008), Ogunleye (2008), Obiora and Igue (2006) Alaba (2003) Adubi and Okumadewa (1999) Egwaikhide (1999) etc. Aliyu (2009) for instance, studied the impact of oil price shock and exchange rate volatility on economic growth in Nigeria, Obiora and Igue (2006) investigated the likely effects of exchange rate volatility on US - Nigeria trade flows, while Ogunleye (2008) and Alaba (2003) focused on exchange rate volatility and foreign direct investment in Nigeria. Despite these efforts, volatility in exchange rate still persists. Could the persistence of the problem be due to inappropriate policies or gaps in the studies already carried out? This is one specific goal of this study. This study departs from the above studies because it focuses on 


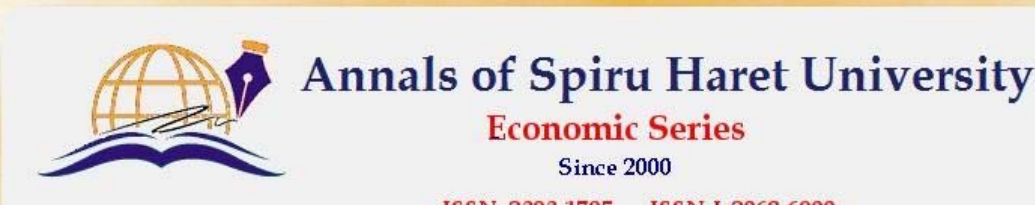

ISSN: 2393-1795 ISSN-L:2068-6900

Issue 1/2018

exchange rate volatility and economic growth from 1970 to 2012 using annual data. It has wider coverage in addition to using a measure of exchange rate volatility.

\subsection{Objectives of the study}

The main objective of the study is to investigate the role of exchange rate fluctuations on Nigerian macroeconomic variables. The specific objectives include:

1) to examine the effect of exchange rate on the GDP;

2) to find out the effect of inflation on the GDP;

3 ) to determine the effect of money supply on the GDP;

4) to investigate the effect of oil revenue on the GDP.

\section{Review of related literature}

\subsection{Conceptual literature}

Exchange rate volatility refers to persistent fluctuations of exchange rate, which often results in persistent depreciation of the home currency. Therefore, exchange rate volatility exposes economic agent to a greater exchange rate risk. However, exchange rate fluctuations can be anticipated or unanticipated. The unanticipated fluctuation has more significant effect as it determines aggregate demand through exports, imports, and the demand for domestic currency, and determines aggregate supply through the cost of imported intermediate goods [Kandil \& Mirzaie, 2008]. In other words, an unanticipated exchange rate fluctuation boosts demand of exports and reduces imports level as it raises the price of importable goods and services.

The exchange rate between the two countries' currencies is always associated with cross border capital and fund movements, thereby with cross border flows of goods and services. Changes in the exchange rate, depreciation or appreciation of the currency, have a significant effect on trade flows and profound implications for the overall economic growth [Shehu \& Youtang, 2012]. Domestic currency depreciation leads to an improvement in exports by the domestic country, and helps achieve positive trade balance.

\subsection{Theoretical framework}

The earliest and leading theoretical foundation for the choice of exchange rate regimes rests on the optimal currency area (OCA) theory, developed by Mundell (1961) and McKinnon (1963). This literature focuses on trade, and stabilization of the business cycle. It is based on concepts of the symmetry of shocks, the degree of openness, and labour market mobility. According to the 108 


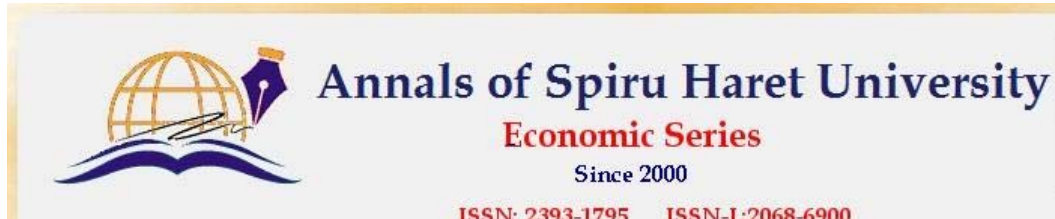

ISSN: 2393-1795 ISSN-I-2068-6900

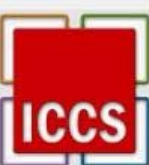

Issue 1/2018

theory, a fixed exchange rate regime can increase trade and output growth by reducing exchange rate uncertainty and thus the cost of hedging, and also encourage investment by lowering currency premium from interest rates. However, on the other hand, it can also reduce trade and output growth by stopping, delaying or slowing the necessary relative price adjustment process.

Later theories focused on financial market stabilization of speculative financial behaviour as it relates particularly to emerging economies. According to the theory, a fixed regime can increase trade and output growth by providing a nominal anchor and the often needed credibility for monetary policy by avoiding competitive depreciation, and enhancing the development of financial markets [see Barro \& Gordon (1983), Calvo (2003), Edwards \& Savastano (2000), Eichengreen et al. (1999), and Frankel (2003) among others].

On the other hand, however, the theory also suggests that a fixed regime can also delay the necessary relative price adjustments and often lead to speculative attacks. Therefore, many developing and emerging economies suffer from a "fear of floating" in the words of Calvo and Reinhart (2002), but their fixed regimes also often end in crashes when there is a "sudden stop" of foreign investment [Calvo, 2003] and capital flight follows, as was evident in the East Asian and Latin American crises and some sub-Saharan African countries.

Not surprisingly, there is little theoretical consensus on this question of regime choice and subsequent economic growth in the development economics literature as well. While the role of a nominal anchor is often emphasized, factors ranging from market depth (or the lack of it), political economy, institutions and so on often lead to inclusive suggestions as to which exchange rate regime is appropriate for a developing country [Frankel et al., 2001; Montiel, 2003; Montiel \& Ostry, 1991]. The literature in development economics acknowledges the importance of the effects of the level of development on the relationship between regime and growth [see Berg, Borensztein \& Mauro (2002), Borensztein \& Lee (2002), Lin (2001), McKinnon \& Schnabel (2003), and Mussa et al. (2000) among others].

\subsection{Empirical literature}

The literature is replete on the effect of exchange rate fluctuations on macroeconomic variables in Nigeria, but these empirical literatures have no consensus on the effect of exchange rate on growth. Thus, the divergence of the findings has necessitated further empirical researches aimed at proffering more robust explanations to the forex-growth nexus. The empirical literature on the subject is also replete in Nigeria. Hence, this review is mainly centred on Nigerian 


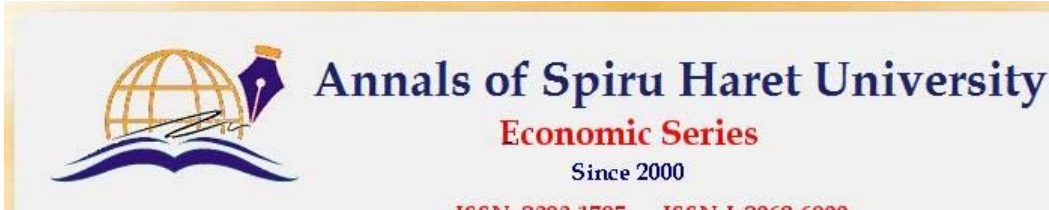

ISSN: 2393-1795 ISSN-L:2068-6900

\section{Issue 1/2018}

empirical research and findings. Some of the empirical works in Nigeria on the relationship between exchange rate and growth are shown below:

Akpan (2008) focused on the implications of exchange rate movement on economic growth. The ordinary least square (OLS) technique was adopted using time series data on exchange rate movement, volatility of exchange rate (EXCHR), labour force, gross domestic investment and technology. Volatility of exchange rate is measured by three years moving average of standard deviation of real exchange rate. The paper maintains that, in view of the positive relationship between exchange rate, volatility and economic growth in Nigeria, exchange rate policy should be designed to bridge the savings investment gap so as to enhance government revenue, as well as reduce the fiscal lacuna through the curtailing of deficit geared at increased and sustained economic growth.

Aliyu (2009) assessed the impact of oil price shock and real exchange rate volatility on real economic growth in Nigeria based on quarterly data from 1986, Q1 to 2007, Q4. The empirical analysis starts by analysing the time series properties of the data, which is followed by examining the nature of causality among the variables. Furthermore, the Johansen VAR-based co-integration technique is applied to examine the sensitivity of real economic growth to changes in oil prices and real exchange rate volatility in the long run, while the short run dynamics was checked using a vector error correction model. Results from ADF and PP tests show evidence of unit root in the data and Granger pair wise causality test revealed unidirectional causality from oil prices to real GDP and bidirectional causality from real exchange rate to real GDP and vice versa. Findings further show that oil price shock and appreciation in the level of exchange rate exert positive impact on real economic growth in Nigeria.

Akpokodje (2009) explored the exports and imports effects of exchange rate volatility with specific reference to the non-Communaute Financiere Africaine (non-CFA) countries of Africa during the period 1986-2006. The countries chosen included Ghana, Lesotho, Malawi, Nigeria, Sierra Leone, South Africa, Uganda and Zambia. A GARCH approach was employed to generate on annual basis the real exchange rate volatility series for each country. The study reveals a negative effect of exchange rate volatility on exports and imports in the selected African countries. The adverse effect of exchange rate volatility on exports in the sampled countries, as found in the study, suggests the need for policy interventions that will help to minimize and, where possible, eradicate exchange rate volatility.

Omojimite and Akpokodje (2010) investigated the effect of exchange rate reforms on Nigeria's trade performance during the period 1986-2007. A small positive effect of exchange rate reforms on non-oil exports through the depreciation 110 


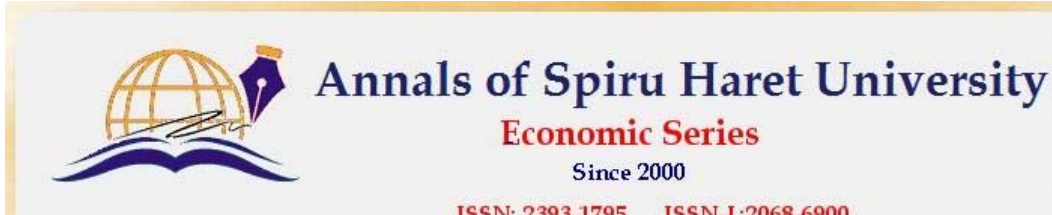

ISSN: 2393-1795 ISSN-L-2068-6900

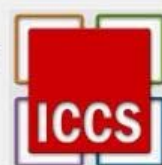

Issue 1/2018

of the value of the country's currency was found. It was also found that the structure of imports, which is pro-consumer goods, remained unchanged even after the adoption of exchange rate reforms. Exchange rate reforms were found not to constrain imports as anticipated. Rather, they stimulate imports, albeit insignificantly.

Ettah, Akpan and Etim (2011) focused on the effects of price and exchange rate fluctuations on agricultural exports (cocoa) in Nigeria. An export supply function for cocoa was specified and estimated using the Ordinary Least Squares Regression. Results showed that exchange rate fluctuations and agricultural credits positively affect cocoa exports in Nigeria. Results also revealed that relative prices of cocoa are insignificantly related to quantity of export, however, it has a negative sign, which is in line with the a priori expectation. The result, therefore, implies a positive significant effect of exchange rate volatility on cocoa exports in Nigeria. The study thus posits that since exchange rate has impacted positively on cocoa export in Nigeria, there should be a free market determination of exchange rate for export of cocoa in Nigeria.

Oladipupo and Onotaniyohuwo (2011) investigated the impact of exchange rate on the Nigeria external sector (the balance of payments position) using the Ordinary Least Square (OLS) method of estimation for data covering the period between 1970 and 2008. The study found that exchange rate has a significant impact on the balance of payments position. The exchange rate depreciation can actually lead to improved balance of payments position if fiscal discipline is imposed. It was also found that improper allocation and misuse of domestic credit, fiscal indiscipline, and lack of appropriate expenditure control policies due to centralization of power in government are some of the causes of persistent balance of payments deficits in Nigeria.

Polodoo, Seetanah and Padachi (2011) provided an investigation into the impact of exchange rate volatility on the macroeconomic performance of Small Island Developing States (SIDS). Taking a sample of 15 SIDS, the present study analyses econometrically the impact of exchange rate volatility on major macroeconomic variables, viz economic growth, external trade and foreign direct investment on the SIDS. The paper first constructs the z-score measure, developed by Wolf et al. (2003) as a measure of exchange rate volatility and employs data spanning the period 1999 to 2010 to analyse robust estimates in a static framework, as well as in a dynamic and longitudinal data framework using the Generalised Method of Moments. It also analyses the impact of exchange rate volatility on macroeconomic performance of the economies. The OLS with robust standard errors results indicate that exchange rate volatility impacts negatively on current account balance, but 


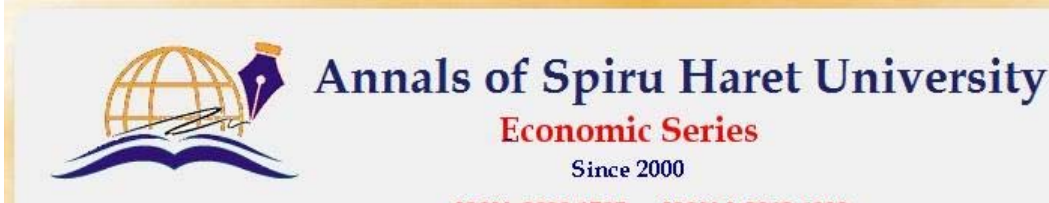

ISSN: 2393-1795 ISSN-L:2068-6900

\section{Issue 1/2018}

positively on the growth rate of the economies studied. In a dynamic setting, however, exchange rate volatility does not influence the macroeconomic variables.

Shehu and Youtang (2012) examined the causal relationship between exchange rate volatility (ERV), trade flows and economic growth of the sub-Saharan African countries with exclusive reference to Nigeria, which is considered a small open economy. The empirical study is based on a time series data over the period of 19702009. The results indicate significant effects of ERV on trade flows and economic growth of Nigeria. The finding support the preference of flexible exchange rate regime over the fixed regime as it facilitates more trade flows in Nigeria.

Adedayo (2012) made a methodological and analytical attempt to determine the precise channel of exchange rate pass-through in Nigeria. The study considered the interest rate and inflation rate channels and then employed a distributed lag model that incorporates a first order lag of exchange rate inclusive of current output level. This approach yield two-variants of the adapted model and the classical ordinary least square method was adopted for estimation. The empirical outcomes indicated that it is only previous exchange rate of naira opposite to US dollar that pass-through interest rate in Nigeria between 1970 and 2010, while neither the current exchange rate of naira opposite to the US dollar nor the previous exchange rate of naira opposite to the US dollar have passed-through inflation rate in Nigeria between 1970 and 2010.

Usman and Adejare (2012) empirically examined the effect of foreign exchange regimes on industrial growth in Nigeria using secondary data obtained from Central Bank of Nigeria Statistical Bulletin covering the period of 1985 to 2005. Multiple regressions were employed to analyze data on such variables as Gross Domestic Product, World Price Index, Per Capita Income, and Net Export. Exchange rate had significant effect on the economic growth with the Adjusted R2 of $69 \%$. Following the outcome of this study, it is therefore concluded that the effect of using Foreign Exchange, World Price Index, Per Capita Income, and Net Export as an inducement for greater performance for stable economic growth are capable of giving stability in prices for manufactured goods.

Azeez, Kolapo and Ajayi (2012) examined the effect of exchange rate volatility on macroeconomic performance in Nigeria from 1986 to 2010. The model formulated depicts Real GDP as the dependent variable, while Exchange Rate (EXR), Balance of Payment (BOP) and Oil Revenue (OREV) are proxied as independent variables. It employs the Ordinary Least Square (OLS) and Johansen cointegration estimation techniques to test for the short and long runs effects respectively. The ADF test reveals that all variables are stationary. OLS results show 112 


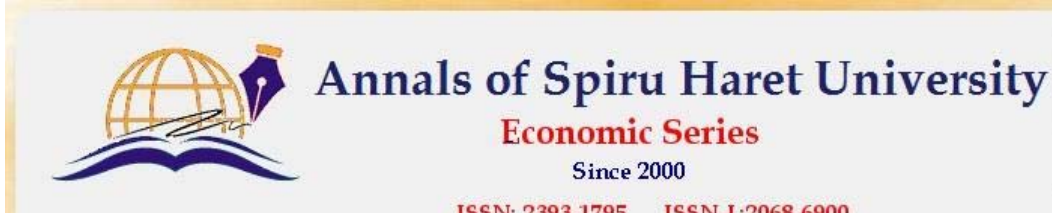

ISSN: 2393-1795 ISSN-L-2068-6900

Issue 1/2018

that OREV and EXR are positively related, while BOP is negatively related to GDP. Further findings reveal that oil revenue and balance of payment exert negative effects, while exchange rate volatility contributes positively to GDP in the long run.

Akpan and Atan (2012) investigated the effect of exchange rate movements on real output growth in Nigeria. Based on quarterly series for the period 1986 to 2010, the paper examined the possible direction of the relationship between exchange rates and GDP growth. The relationship is derived in two ways using a simultaneous equations model within a fully specified (but small) macroeconomic model. A Generalised Method of Moments (GMM) technique was explored. The estimation results suggest that there is no evidence of a strong direct relationship between changes in exchange rate and output growth. Rather, Nigeria's economic growth has been directly affected by monetary variables. These factors have tended to sustain a pattern of real exchange rate, which has been unfavourable for growth. The conclusion is that improvements in exchange rate management are necessary, but not adequate to revive the Nigerian economy. A broad program of economic reform is required to complement the exchange rate policy adopted.

Oyovwi (2012) evaluated the effect of exchange rate volatility on economic growth in Nigeria based on the annual data from 1970 to 2009. A review of the literature reveals that exchange rate volatility can have either positive or negative effect on economic growth. The empirical analysis began with testing for stationarity of the variables by applying the Augmented Dickey-Fuller (ADF). This was followed by co-integration test of the model. The unit root test results show that all variables except exchange rate volatility were integrated at order one, that is $\mathrm{I}(1)$ while exchange rate volatility is integrated at order zero, that is $\mathrm{I}(\mathrm{O})$. Also, cointegration analysis indicated that variables are co-integrated. Employing the Generalised Autoregressive Conditional Heteroscedasticity (GARCH) technique to generate exchange rate volatility, the relationship between exchange rate volatility and economic growth was estimated. Findings further show that in the short run, economic growth is positively responsive to exchange rate volatility, while in the long run, a negative relationship exist between the two variables. The long run result also indicates that increase in oil price depresses economic growth in Nigeria. Thus, the income effect of rising oil price is not felt, while the output effect is evidenced in factory closure and re-location to neighbouring countries.

Umaru, Sa'idu and Musa (2013) investigated the impact of exchange rate volatility on export in Nigeria. The paper employed three models, viz: Ordinary Least Square (OLS); Granger causality test; and ARCH and GARCH techniques and also Augmented Dickey-Fuller technique was used in testing the presence of unit 


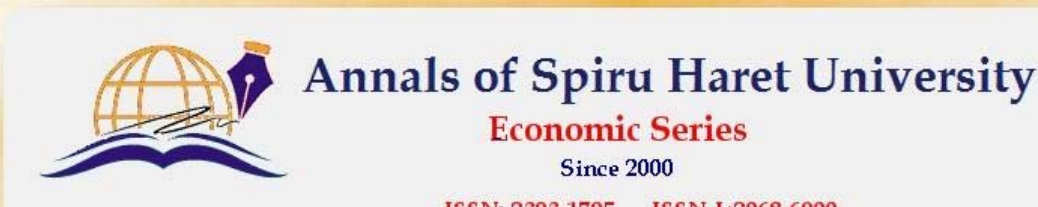

ISSN: 2393-1795 ISSN-L:2068-6900

\section{Issue 1/2018}

root. The results of unit root suggested that all the variables in the model are stationary at first difference, while causality test revealed that there is causation between export and exchange rate in the country, but the causation flows from exchange rate to export. Thus, exchange rate causes export. Furthermore, ARCH and GARCH results suggested that the exchange rate is volatile nevertheless export is found to be non-volatile. The study further showed that exchange rate is impacting positively on export, as shown by the regression results. The elasticity results revealed that, the demand for Nigerian products in the World market is fairly elastic.

Taiwo and Adesola (2013) investigated the impact of unstable exchange rate on bank performance in Nigeria using two proxies for bank performance, namely loan loss to total advances ratio and capital deposit ratio. Government expenditure, interest rate, real gross domestic product were added to exchange rate as independent variables. The two models specified show that the impact of exchange rate on bank performance is sensitive to the type of proxy used for bank performance. Loan loss to total advance ratio shows that fluctuating exchange rate may affect the ability of lenders to manage loans resulting into high level of bad loans, while capital deposit ratio does not have significant relationship with exchange rate.

\section{Methodology}

The study adopted secondary data sourced. Secondary data is the name given to data that have been used for some purpose other than that for which they were originally collected. The data for the study were generated from the CBN Statistical Bulletin, 2015.

The model used in this study is adapted from the exchange rate equation as used by Akpan and Atan (2012). In their model, exchange rate was used as an endogenous variable with inflation rate, growth rate of real GDP, and growth rate of money supply as the explanatory variables. As a modification, this study adapted from Akpan and Atan (2012) and then included inflation and oil revenue that are capable of influencing exchange rate in Nigeria. This could be stated mathematically as follows:

$$
\mathrm{GDP}=\mathrm{f}(\mathrm{EXCH}, \mathrm{INF}, \mathrm{MS}, \mathrm{OIL})
$$

The econometric form of the model is given as:

$$
\mathrm{GDP}_{t}=\mu_{0}+\mu_{1} \mathrm{EXCH}_{t}+\mu_{2} \mathrm{INF}_{\mathrm{t}}+\mu_{3} \mathrm{LnMs}_{t}+\mu_{4} \mathrm{LnOIL}_{t}+\varepsilon_{t}
$$




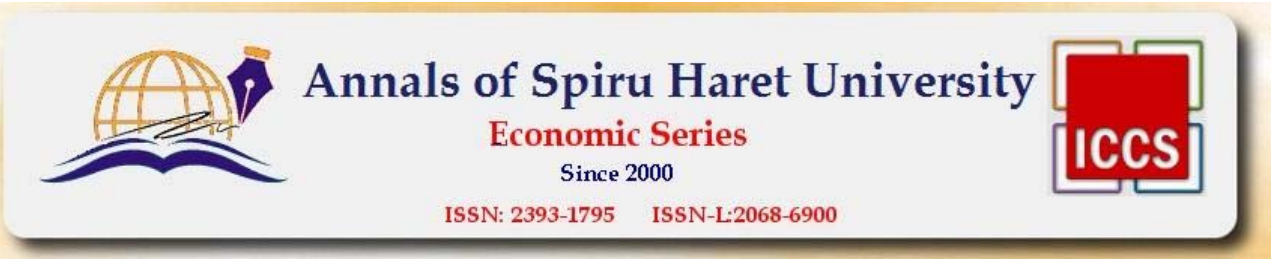

Issue 1/2018

Where:

$\mathrm{GDP}=\mathrm{GDP}$ at current market prices

$\mathrm{EXCH}=$ nominal exchange rate

$\mathrm{INF}=$ rate of inflation (this is the Nigerian Consumer Price Index)

$\mathrm{MS}=$ Money supply $\left(\mathrm{M}_{2}\right)$

OIL $=$ Oil revenue

$\mathrm{Ln}=$ Natural logarithm of the variables used to smoothen possible scholastic effect from variables at level.

$t=$ time subscript

In other words, $\mu_{0}$ is the constant while $\mu_{1}-\mu_{4}$ are the coefficients of the relationships between the independent variables and the dependent variable. $\varepsilon_{t}$ is the stochastic error term for the time period covered by the study.

Following the methodological style of Taiwo and Adesola (2013), the analysis of this study is broken into three parts, the first for fixed exchange regime (1970-1985), the second analysis (model) is the floating exchange regime (19862015), while the third analysis is the whole period (1970 to 2015).

The study employed the Ordinary Least Square (OLS) technique for the analysis. The coefficient of determination $\left(\mathrm{R}^{2}\right)$, F-test, $\mathrm{t}$-test, beta and DurbinWatson were used in the interpretation of the results. The decision rule for test of hypotheses is to rejects the null hypotheses for calculated significance value below $5 \%$ level of significance. Student T-Test measures the individual significance of the estimated independent variables. F-Test measures the overall significance. The coefficient is used to measure the individual contribution of the variables to variation in the dependent variable. Durbin Watson (DW) Statistics tests for auto correlation in the regression.

\section{Analyses and interpretation of results}

The results of the analyses are presented in Table no. 1. The results comprised three multiple regression analyses. Column 1 is the result of multiple regression analysis for the effect of exchange rate on macroeconomic variables in the fixed exchange rate era (1970 to 1985), column 2 is for floating exchange rate era (1986 to 2015) while column 3 captured the whole time periods (1970 to 2015).

Coefficient of determination $\left(\mathrm{R}^{2}\right)$ and $\mathrm{F}$-value are used to analyse overall impact of exchange rate changes on economic growth while the coefficients are used to test for the various hypotheses. 


\section{Issue 1/2018}

The Durbin Watson is used to test for the reliability of the models. The results from the analysis are 1.981 (fixed exchange rate era), 2.039 (floating exchange rate era) and 1.918 for all the periods. Since the results are approximately equal to 2 , we conclude that the models have no autocorrelation and therefore are reliable. The results of the analyses are shown in Table no. 1 below:

Table no. 1. Multiple Regression of the Effect of Exchange Rate on Economic Growth for Three Periods (All = 1970-2015; Pre SAP = 1970-1985; Post-SAP = 1986-2015)

\begin{tabular}{|l|c|c|c|}
\hline Model/Variable & $\mathbf{1}$ & $\mathbf{2}$ & $\mathbf{3}$ \\
\hline Period & $\begin{array}{c}\text { 1970-1985 } \\
\text { (Fixed Exchange } \\
\text { Era) }\end{array}$ & $\begin{array}{c}\text { 1986-2015 } \\
\text { (Floating Exchange } \\
\text { Era) }\end{array}$ & $\begin{array}{c}\text { 1870-2015 } \\
\text { (All Time Period) }\end{array}$ \\
\hline Constant & $-44.182^{*}$ & $0.275^{* *}$ & $-82.162^{*}$ \\
\hline EXCH & 0.654 & $-0.814^{*}$ & $-0.407^{*}$ \\
\hline INF & -0.411 & $0.321^{*}$ & $-0.251^{* *}$ \\
\hline MS & -1.544 & $0.097^{*}$ & $0.453^{* *}$ \\
\hline OIL & $8.030^{* *}$ & $0.725^{*}$ & $4.012^{*}$ \\
\hline \multicolumn{4}{|c|}{} \\
\hline Adjusted R2 & 0.852 & 0.985 & 0.732 \\
\hline DW & 1.981 & 2.039 & 1.918 \\
\hline F-Value (Prob) & $29.461\left(0.020^{*}\right)$ & $12.064\left(0.002^{*}\right)$ & $47.743\left(0.000^{*}\right)$ \\
\hline
\end{tabular}

$* \& * *=1 \%$ and $5 \%$ level of significance

Source: SPSS 17 Analysis.

\section{Interpretation of results}

The extent to which changes in economic growth (GDP) can be explained by exchange rate, inflation, money supply and oil revenue is measured with the results of the coefficient of determination $\left(\mathrm{R}^{2}\right)$. The Adjusted $\mathrm{R}^{2}$ is adopted to avoid overestimation of the influence. The results indicate that the $A d j R^{2}$ is 0.852 (fixed exchange rate era), 0.985 (floating exchange rate era) and 0.732 for all the periods.

From the result, it can be seen that about $85 \%$ of the changes in macroeconomic indicators are explained in the fixed exchange era. In the floating exchange era, $99 \%$ was explained while the whole periods have $73 \%$ explanatory power. This indicates that the floating exchange era (1986 to date) is more effective in explaining economic trend in Nigeria. This implies that floating exchange is a better economic policy than the fixed exchange era. However, the results suggest 

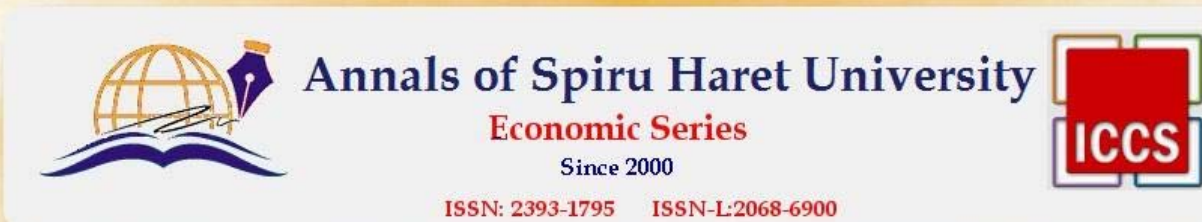

ISSN: $2393-1795 \quad$ ISSN-L-2068-6900

Issue 1/2018

that exchange rate movement is a good indicator for monitoring economic growth in Nigeria.

F-Value (Prob) is used to test the significance of the overall results. The issue here is whether exchange rate movements and the control variables (INF, MS, and OIL) have significant effect on economic growth. The results are $29.461\left(0.020^{*}\right)$ for fixed exchange rate era, $12.064\left(0.002^{*}\right)$ for floating exchange rate era and 47.743 $\left(0.000^{*}\right)$ for all the periods. The results indicate that exchange rate movement has significant impact on economic growth in Nigeria in all the exchange rate management eras. This implies that exchange rate has always been a key economic indicator for Nigeria.

\section{Hypotheses testing}

Each of the hypotheses of the study is tested using the t-value, while the direction of the relationship is determined by the coefficient of the variables. The equation of the regression is shown below for each of the periods (exchange rate era).

Fixed Exchange Era:

$\mathrm{GDP}=-44.182 *+1.7694 \mathrm{EXCH}-0.411 \mathrm{INF}-0.544 \operatorname{lnMs}+8.030 \mathrm{LnOIL} * *$

Floating Exchange Era:

$\mathrm{GDP}=0.275^{* *}-0.814 \mathrm{EXCH}^{*}+0.321 \mathrm{INF}^{*}+0.097 \mathrm{LnMs}^{*}+0.725 \mathrm{LnOIL}^{*}$

All Time Period:

$\mathrm{GDP}=-82.162 *-0.407 \mathrm{EXCH}^{* *}-0.251 \mathrm{INF}^{* *}+0.453 \mathrm{LnMs}^{* *}+4.012 \mathrm{LnOIL} *$

\section{Effect of exchange rate on the GDP}

$\mathrm{Ho}_{1}$ : Exchange rate fluctuation has no significant positive effect on GDP.

The coefficients of $\mathrm{EXCH}$ are $1.7694 \mathrm{EXCH}$ (for fixed exchange era), $-0.814 \mathrm{EXCH}^{*}$ (for floating exchange era), and $-0.407 \mathrm{EXCH}^{* *}$ (for all-time periods). The results showed that the exchange rate has positive relationship with economic growth during the fixed exchange era and negative relationship in the floating and all the eras. This shows that during the fixed exchange era, a percentage increase in exchange rate increases GDP by $176 \%$. However, during the floating exchange rate 


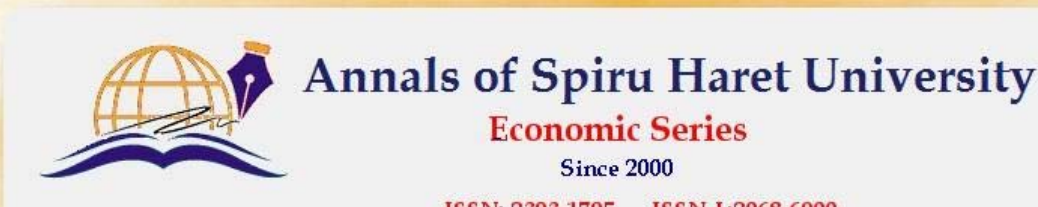

ISSN: 2393-1795 ISSN-L:2068-6900

Issue 1/2018

and all the periods, a percentage increase in exchange rate decreases the growth of GDP by $81 \%$ and $40 \%$, respectively. The probability of the coefficients (indicating * and $* *$ ) indicates that there is a significant relationship between exchange rate and GDP in each of the eras (floating, fixed and all-time).

\section{Effect of inflation on the GDP}

$\mathrm{Ho}_{2}$ : Inflation has no significant positive effect on GDP.

The coefficients of INF are -0.411INF (for fixed exchange era), $0.321 \mathrm{INF}^{*}$ (for floating exchange era), and $-0.251 \mathrm{INF}^{* *}$ (for all-time periods). The results showed that inflation has positive relationship with economic growth during the floating exchange era and negative relationship in the fixed and all the eras. This shows that during the floating exchange era, a percentage increase in inflation rate increases GDP by $32 \%$. However, during the fixed exchange rate and all the periods, a percentage increase in exchange rate decreases the growth of GDP by $41 \%$ and $25 \%$, respectively. The probability of the coefficients (indicating * and **) indicates that there is a significant relationship between inflation and GDP in floating era, as well as all-time period, but the fixed exchange era does not show significant effect of inflation on GDP.

\section{Effect of money supply on the GDP}

$\mathrm{Ho}_{3}$ : Money supply has no significant positive effect on GDP.

The coefficients of MS are -0.544LnMs (for fixed exchange era), 0.097LnMs* (for floating exchange era), and $0.453 \mathrm{LnMs}^{* *}$ (for all the periods). The results showed that money supply has negative relationship with economic growth during the fixed exchange era and positive relationship in the floating and all-time era. This shows that during the floating and all-time exchange eras, a percentage increase in money supply increases GDP by $97 \%$ and $45 \%$, respectively, while a percentage increase in money supply decreases the growth of GDP by $54 \%$ in the fixed exchange rate era. The probability of the coefficients (indicating * and $* *$ ) indicates that there is a significant relationship between money supply and GDP in floating era, as well as all the period but the fixed exchange era does not show significant effect of money supply on GDP.

\section{Effect of oil revenue on the GDP}

$\mathrm{Ho}_{4}$ : Oil revenue has no significant positive effect on GDP.

The coefficients of OIL are 8.030 $\mathrm{LnOIL}^{* *}$ (for fixed exchange era), $0.725 \mathrm{LnOIL} *$ (for floating exchange era), and $4.012 \mathrm{LnOIL}^{*}$ (for all-time periods). 

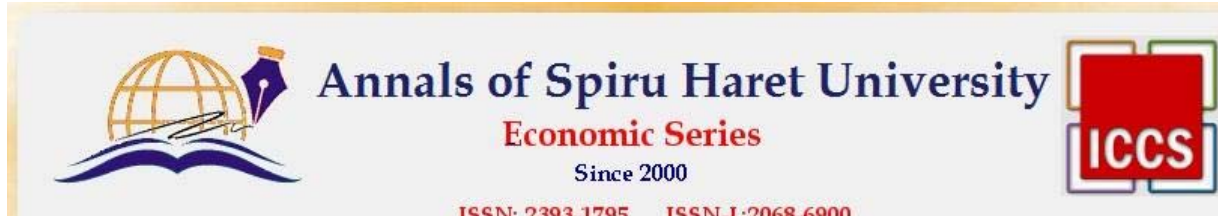

ISSN: $2393-1795$ ISSN-L-2068-6900

Issue 1/2018

The results showed that oil revenue has positive relationship with economic growth during the fixed, floating and all-time eras. This shows that a percentage increase in oil revenue increases GDP by $803 \%, 73 \%$ and $401 \%$ during the fixed, floating and all-time periods, respectively. The probability of the coefficients (indicating * and **) indicates that there is a significant relationship between oil revenue and GDP in each of the eras (floating, fixed and all-time). This implies that oil revenue has positive effect in Nigeria and has remained the mainstay of the economy.

\section{Conclusion and recommendations}

The results have shown that exchange rate movement is a good indicator for monitoring economic growth in Nigeria. This indicates that exchange rate has always been a key economic indicator for Nigeria. The floating exchange period has outperformed the fixed exchange rate in terms of contribution inflation, money supply and oil revenue to economic growth. This indicates that the floating exchange rate has been a better economic regime for sustainable economic growth in Nigeria. From the findings, it is evident that oil revenue has positive effect in Nigeria and has remained the mainstay of the economy.

Based on the results of this research and the realization of effect of Foreign Exchange on the Real Growth in Nigerian economy, the following recommendations are made:

1. Positive exchange rate stock should be monitored regularly, so as not to allow those that find exchange rate as an avenue of investment, such as banks and the public, carry out their business, which is more devastating to the economy.

2. Government should stimulate export diversification in the area of agriculture, agro-investment, and agro-allied industries, oil allied industries such will improve Foreign Exchange Earnings on Real growth in Nigerian economy.

3 . Finally, the government should influence the foreign exchange rate, by positive economic reforms that will reduce the adverse effect of unstable foreign exchange rate on the Nigerian economy with respect to trade flow.

\section{References}

1. Adedayo, A. O., "Exchange rate pass-through in Nigeria: A dynamic evidence," European Journal of Humanities and Social Sciences, 16(1), (2012): 785-801. Retrieved from www.journalsbank.com/ejhss_16_2.pdf.

2. Adubi, A. A. \& Okumadewa, F., "Price exchange rate volatility and Nigeria's trade flows: A dynamic analysis," AERC Research paper No. 87 (African Economic Research Consortium, Nairobi, Kenya, 1999). 
Issue 1/2018

3. Alaba, O., "Exchange rate uncertainty and foreign direct investment in Nigeria," A Paper Presented at the WIDER Conference on Sharing Global Prosperity, Helsinki, Finland, 6-7 September 2003.

4. Akpan I. P., "Foreign exchange market and economic growth in an emerging petroleum based economy: Evidence from Nigeria (1970-2003)," African Economic Business Review, 6(2), (2008): 46-58. Retrieved from www.theaebr.com/Vol6No2Fall2008 Akpan.pdf.

5. Akpan, E. O. \& Atan, J. A., "Effects of exchange rate movements on economic growth in Nigeria," CBN Journal of Applied Statistics, 2(2), (2012): 1-14. Retrieved from www. cenbank.org/out/2012/ccd/cbn\%20jas\%20vol\%202\%20no\%202_article\%20one.pdf.

6. Akpokodje, G., "Exchange rate volatility and external trade: The experience of selected African countries." In. Adeola Adenikinju, Dipo Busari and Sam Olofin (ed.) Applied Econometrics and Macroeconomic Modelling in Nigeria (Ibadan University press, 2009).

7. Aliyu, S. U., Impact of oil price shock and exchange rate volatility on economic growth in Nigeria: An Empirical Investigation (Central Bank of Nigeria, 2009).

8. Azeez, B. A., Kolapo, F. T. \& Ajayi, L. B., "Effect of exchange rate volatility on macroeconomic performance in Nigeria," Interdisciplinary Journal of Contemporary Research in Business, 4(1), (2012): 149-155.

9. Barro, R. J. \& Gordon, D. B., "Rules, discretion, and reputation in a model of monetary policy," Journal of Monetary Economics, 12, (1983): 101-20.

10. Berg, A., Borensztein, E. \& Mauro, P., "An Evaluation of monetary regime options for Latin America," The North American Journal of Economics and Finance, 13, (2002): 213-235.

11. Bobai, F. D., Ubangida, S. \& Umar, Y. S., "An assessment of exchange rate volatility and inflation in Nigeria," Journal of Emerging Issues in Economics, Finance and Banking (JEIEFB) 1(4), (2013): 321-340. Retrieved from www.globalbizresearch.com

12. Borensztein, E. \& Lee, J-W., "Financial crisis and credit crunch in Korea: Evidence from Firm-level data," Journal of Monetary Economics, 49(4), (2002): 53-75

13. Calvo, G., "Explaining Sudden stop, growth collapse and bop crisis: The case of discretionary output tax." The Mundell Fleming Lecture for the Third Annual IMF Research Conference (Washington, DC, 2003).

14. Calvo, G. \& Reinhart, C., "Fear of floating," Quarterly Journal of Economics, 117(2), (2002): 379-408.

15. Edwards, S. \& Savastano, M. A., "Exchange rates in emerging economies: What do we know? What do we need to know?" In Economic Policy Reform: The Second Stage, ed. by Anne O. Krueger (Chicago: University of Chicago Press, 2000), pp. 453-510.

16. Eichengreen, B. \& Irwin, D. A., "Trade blocs, currency blocs and the reorientation of trade in the 1930s," Journal of International Economics, 38, (1995): 1-24.

17. Egwaikhide, F. O., "Determinants of imports in Nigeria: A dynamic specification. African Economic Research Consortium," (AERC) Research Paper, No. 91 (1999). 


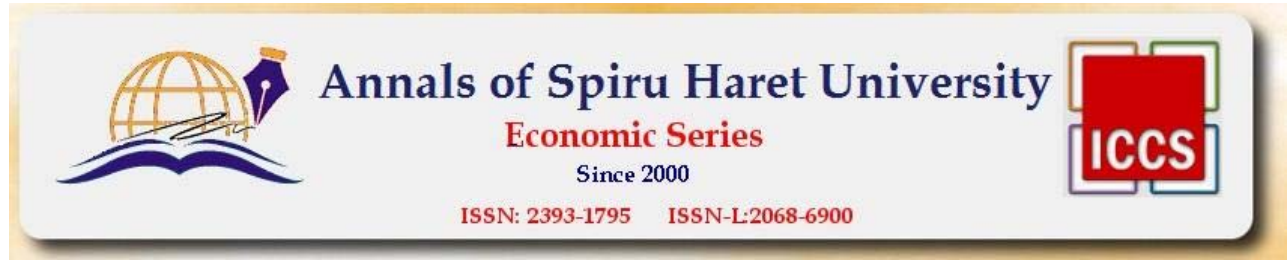

Issue 1/2018

18. Ettah, B. E., Akpan, O. D. \& Etim, R. S., "Effects of price and exchange rate fluctuations on agricultural exports in Nigeria," International Journal of Economic Development Research and Investment, 2(1), (2011): 1-10. Retrieved from www.icidr.org/ijedri vol2no1_april2011/Effects\%20of\%20Price $\% 20$ and $\% 20$ Exchange $\% 20$ Rate $\% 20$ Fluctua tions $\% 20$ on\%20Agricultural\%20Exports\%20in\%20Nigeria.pdf

19. Frankel, J., Fajnzylber, A. E., Schmukler, S. L. \& Servén, L., "Verifying exchange rate regimes," Journal of Development Economics 66(2), (2001): 351-86.

20. Frankel, J., "Experience and lessons from exchange rate regimes in emerging economies," Monetary and Financial Cooperation in East Asia (Asian Development Bank, Macmillan, 2003).

21. Kandil, M., "Exchange rate fluctuations and economic activity in developing countries: Theory and evidence," Journal of Economic Development, 29(1), (2004): 85-108.

22. Kandil, M. \& Mirzaie, I. A., "Comparative analysis of exchange rate appreciation and aggregate economic activity: Theory and evidence from Middle Eastern countries," Bulletin of Economic Research 60(1), (2008): 45-96.

23. Lin, J. Y., "WTO accession and financial reform in China," Cato Journal, 21(1), (2001): 13-18.

24. McKinnon, R., "Optimal currency areas,” American Economic Review, 53, (1963): 717 724.

25. McKinnon, R. \& Schnabl, G., "Synchronized business cycles in East Asia and fluctuations in the Yen/Dollar exchange rate," The world economy, 26(8), (2003): 1067-1088.

26. Montiel, P. J., Macroeconomics in Emerging Markets (Cambridge: Cambridge University Press, 2003).

27. Montiel, P. J. \& Ostry, J., "Macroeconomic implication of real exchange rate targeting in developing countries," IMF Working Paper 91/29 (International Monetary Fund, 1991).

28. Mussa, M., Masson, P., Swoboda, A., Jadresic, E., Mauro, P. \& Berg, A., Exchange Rate Regimes in an Increasingly Integrated World Economy. IMF Occasional Paper No. 193 (Washington, DC, 2000).

29. Mundell, R., “A theory of optimal currency areas," American Economic Review 51(4), (1961): 657-65.

30. Obiora, K. I. \& Igue, N. N., "Exchange rate volatility and US-Nigeria trade flows: An econometric appraisal of the evidence," Paper Presented at the 11th Annual Conference of the African Econometric Society (Dakar, Senegal, 5-7 July 2006).

31. Ogunleye, E. K., "Natural resource abundance in Nigeria: from dependence to development, resources policy," European Journal of Economics, Finance and Administrative Sciences, 55, (2008): 45-61.

32. Oladipupo, A. O. \& Onotaniyohuwo, F. O., "Impact of exchange rate on balance of payment in Nigeria," An International Multidisciplinary Journal, 5 (4), (2011): 73-88. 


\section{Annals of Spiru Haret University \\ Economic Series \\ Since 2000 \\ ISSN: 2393-1795 ISSN-L:2068-6900}

\section{Issue 1/2018}

33. Olisadebe, E.U., "An appraisal of recent exchange rate policy measure in Nigeria," CBN Economic and Financial Review, 29(2), (1991): 27-32.

34. Omojimite, B. U. \& Akpokodje, G., "The impact of exchange rate reforms on trade performances in Nigeria," Journal of Social Sciences, 23(1), (2010): 86-94.

35. Onwumere, J. U. J., Business and economic research method (Enugu: Vougasen Publishers, 2009).

36. Oyovwi, D. O., "Exchange rate volatility and economic growth in Nigeria," Mediterranean Journal of Social Sciences, 3 (3), (2012): 399-407.

37. Polodoo, V., Seetanah, B. \& Padachi, K., "Exchange rate volatility and macroeconomic performance in small island developing states," A Paper Presented at the Uom-Wcp International Conference at Le Meridien, Mauritius on 22 December 2011. Retrieved from www.freit.org/WorkingPapers/Papers/.../FREIT457.pdf

38. Shehu, A. A. \& Youtang, Z., "Exchange rate volatility, trade flows and economic growth in a small open economy," International Review of Business Research Papers, 8(2), (2012): 118-131. Retrieved from www.bizresearchpapers.com/9.\%20Abba.pdf

39. Taiwo, O. \& Adesola, O. A., "Exchange rate volatility and bank performance in Nigeria," Asian Economic and Financial Review, 3(2), (2013): 178-185. Retrieved from www.aessweb.com/download.php?id=1769.

40. Todaro, P. M. \& Smith, C. S., Economic development (Pearson Education Limited Delhi 110092, India, 2004).

41. Umaru, A., Sa'idu, B. M. \& Musa, S., "An empirical analysis of exchange rate volatility on export trade in a developing economy," Journal of Emerging Trends in Economics and Management Sciences, 4(1), (2013): 42-53.

42. Usman, O. A. \& Adejare, A. T., "The effects of foreign exchange regimes on industrial growth in Nigeria, Global Advanced Research Journal of Economics," Accounting and Finance, 1(1), (2012): 1-8. 